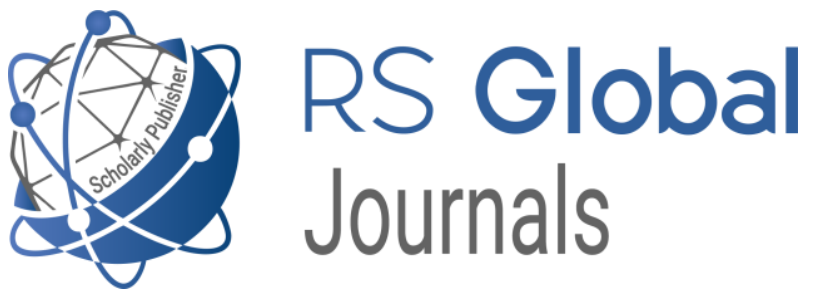

Scholarly Publisher

RS Global Sp. z O.O.

ISNI: 0000000484952390

Dolna 17, Warsaw, Poland 00-773

Tel: +48226022703

Email: editorial_office@rsglobal.pl

JOURNAL International Journal of Innovative Technologies in Social Science

p-ISSN 2544-9338

e-ISSN 2544-9435

PUBLISHER RS Global Sp. z O.O., Poland

ARTICLE TITLE SAYAT NOVA AND THE ARMENIAN ASHUGH ART

AUTHOR(S) Harutyunyan H. H., Asatryan A. H., Khachatryan D. K.

Harutyunyan H. H., Asatryan A. H., Khachatryan D. K. (2021)

ARTICLE INFO Sayat Nova and the Armenian Ashugh Art. International Journal of Innovative Technologies in Social Science. 4(32). doi:

10.31435/rsglobal_ijitss/30122021/7733

DOI

https://doi.org/10.31435/rsglobal_ijitss/30122021/7733

RECEIVED

30 October 2021

ACCEPTED 14 December 2021

PUBLISHED

18 December 2021

LICENSE

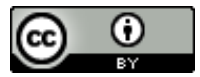

This work is licensed under a Creative Commons Attribution

4.0 International License.

(C) The author(s) 2021. This publication is an open access article. 


\title{
SAYAT NOVA AND THE ARMENIAN ASHUGH ART
}

\author{
Harutyunyan H. H., PhD in Art, Shirak Centre for Armenian Studies of NAS RA, Gyumri, Republic of \\ Armenia \\ Asatryan A. H., Researcher, Shirak Centre for Armenian Studies of NAS RA, Gyumri, Republic of \\ Armenia
}

Khachatryan D. K., Researcher, Shirak Centre for Armenian Studies of NAS RA, Gyumri, Republic of

Armenia

DOI: https://doi.org/10.31435/rsglobal_ijitss/30122021/7733

\section{ARTICLE INFO}

Received 30 October 2021

Accepted 14 December 2021

Published 18 December 2021

\section{KEYWORDS}

Sayat-Nova, poetry, troubadour (ashugh), traditional music, Song, Armenian compositions multiethnic.

\begin{abstract}
The article is dedicated to the problems of the creative heritage of the famous Armenian troubadour Sayat Nova. The poetic legacy of this great singer of man, love, beauty and justice is one of the most striking revelations of the Armenian (and not only Armenian) creative genius. Thanks to its universal human character, nationality, social richness and unique poetic art, the word Sayat-Nova still sounds today with the same force, in tune with the most intimate feelings of the human soul. The popularity of Sayat-Nova's poetry, in particular among the peoples of the Caucasus, is absolutely exceptional. SayatNova is an outstanding musician-inventor and there is a regular need to reflect on new developments in the study of his song heritage.
\end{abstract}

Citation: Harutyunyan H. H., Asatryan A. H., Khachatryan D. K. (2021) Sayat Nova and the Armenian Ashugh Art. International Journal of Innovative Technologies in Social Science. 4(32). doi: 10.31435/rsglobal_ijitss/30122021/7733

Copyright: (C) 2021 Harutyunyan H. H., Asatryan A. H., Khachatryan D. K. This is an open-access article distributed under the terms of the Creative Commons Attribution License (CC BY). The use, distribution or reproduction in other forums is permitted, provided the original author(s) or licensor are credited and that the original publication in this journal is cited, in accordance with accepted academic practice. No use, distribution or reproduction is permitted which does not comply with these terms.

Introduction. Sayat-Nova has a great service in the field of late medieval Armenian literature and careful culture. He is the culmination of the Armenian troubadour lyric poetry, an artist generously endowed with nature, who revived the cowboy art, which had changed due to the division and decline of the Armenian political independent life, put it in a new direction, revolutionizing the 16th century. The snow and the content of the ashugh poem that has come to an end.

In the Caucasus, Sayat-Nova contrasted the Turkish-language games of nomadic singers and musicians in the Middle East, which were widespread in the Middle East, and partly past and stateless, with songs in Armenian and deeply expressing human feelings. the game and personal lyric poetry.

$\mathrm{He}$ is the first poet in the Armenian reality who has played a great role in the careful rapprochement of the peoples of the Caucasus with his multilingual work. From the XVIII century. From the second half, he was influenced by many Georgian, Azerbaijan and Armenian poets and troubadours. Sayat-Nova. It has a firm place in the history of Georgian lyric poetry.

History shows that Sayat-Nova was a hugely influential poet and musician throughout Armenia. Even though he spent most of his life in a society steeped in religious fervour he wrote in a romantic style, never afraid to express his true feelings about love and life. He never allowed religion to influence his work in any way with most of his poems and compositions being very much of a secular nature.

At least 220 songs are known to have come from his pen but it is very likely that he wrote many more. They were mostly written in the traditional Armenian style, in a variety of languages including Persian, Georgian and Armenian.

Sayat-Nova was killed in September 1795 at the Haghpat monastery by soldiers who were part of the invading armies of the Shah of Iran. He was 82 years old and his body was interred at the Cathedral of Saint George in Tbilisi. 
The poetic legacy of this great singer of man, love, beauty and justice is one of the most striking revelations of the Armenian (and not only Armenian) creative genius. Thanks to its universal human character, nationality, social richness and unique poetic art, the word Sayat-Nova still sounds today with the same force, in tune with the most intimate feelings of the human soul. The popularity of Sayat-Nova's poetry, in particular among the peoples of the Caucasus, is absolutely exceptional. Many lines and passages of his songs, created in Armenian, Georgian and Azerbaijani languages, which are truly amazing clots of folk wisdom, have long turned into winged words. This phenomenon is perhaps the highest recognition and appreciation of the poet's artistic merits ...

Relying on the achievements of national artistic thinking, in particular on the achievements of Armenian medieval poetry, as well as folklore (not only Armenian, but also Georgian and Azerbaijani), successfully continuing the traditions of medieval lyric poetry, at the same time creatively assimilating and developing on the national soil the most valuable elements of the Eastern Ashug poetry as a whole, outstanding masters of Armenian poetic art, and first of all Sayat-Nova, liberated Armenian poetry from alien bonds that were tightening it and directed it along the path of national development. It seems that, first of all, it is in this that one should see the great creative merit of Sayat-Nova in the development of all Armenian poetry ...

The original and rich poetic heritage of Sayat-Nova is the most vivid expression of the distinctive features of Armenian (and not only Armenian) poetry of the 18th century, which is characterized by tendencies aimed at reviving the humanistic ideas of centuries-old national literature, further strengthening the process of democratization of literature, deepening its social beginning, critical attitude to the surrounding reality and the feudal foundations of life, improvement of traditional and search for new art forms, attention to oral folk art, thematic and genre diversity, expansion of literary ties with other peoples. Armenian poetry of this period is notable for its complexity and emotional richness, a national outlook and a variety of expressive means, a passionate call to enjoy the miracle of real life and nature, skill in revealing the subtle nuances of a complex inner world of a person. The poetry of the 18th century not only used all the achievements of medieval Armenian poetry, but also determined the further continuity of the traditions of national poetry, at the same time preparing the ground for its development at a new historical stage. The poetry of the 18th century owes this primarily to the work of such poets as Bagdasar Dpir, Petros Kapantsi, Shamchi Melko, Hovhannes Karnetsi, Ovnatan Nagash and especially Sayat-Nova ...

The democratic essence of Sayat-Nova's poetry is determined by his understanding of the place of art in life, which was based on his social thinking, love of the people and humanistic outlook. In one of his poems, the poet calls himself a "servant of the people," expressing his thoughts, aspirations and hopes, "healing" his emotional wounds, and sees his only and high calling in faithful and selfless service to the common people ...

The contemplative spirit is deeply alien to Sayat-Nova's poetry. His deep, complex poetic reflections were born of living and contradictory reality, which is why his lyrics, and especially philosophical reflections, are distinguished by an active attitude to life, carry deep and original generalizations. His poetic word is characterized by true passion, great public sound ... The social tragedy of the poet, called to become the defender of the commoner and justice, is due to the conflict between his humanistic ideals and feudal reality. Particularly deep pain is inflicted on the poet by social injustices and inequality of people in the world created by God ...

Tragically experiencing the hard lot of the common people and man, the poet dreams of retiring, "flying away like a nightingale," as he says, from this soulless world. However, this desire is not an escape from life, as it might seem at first glance, but a kind of protest against the misanthropic essence of the feudal world. It is extremely remarkable that, presenting the reality of his day in such gloomy tones and exposing the essence of social and social evil, the poet does not become a misanthrope or pessimist, does not lose faith in the future and in man ...

"Sayat-Nova's Armeno-Azeri songs reveal him to be apious Armenian Christian, quite proud of this identity, but nonetheless one who takes

Islamic doctrines seriously. It is striking that his religious views do not prevent him from composing songs and paraenesis in Muslim religious traditions, betraying his powerful empathy. His broadmindedness benefitted his legacy under the mid-20th century Soviet rhetoric of "Friendship of Peoples", but has suffered outside the Armenian sphere during periods of nationalist fervor whose scale of values is the antithesis of the bardic tradition in according the highest premium to one's 
ethnonationalist identity. Still, his multilingualism and religious broad-mindedness, plus his sincerity in love, and his opposition to injustice, all prepare the ground for him to be the symbol of genuine interethnic harmony in the region" [7, p. 286].

In the poetic heritage of Sayat-Nova, songs belonging to the philosophical and edifying genre occupy a special place (just like the edifying and moralizing motives in other songs). Although there are relatively few of them, they nevertheless give a new color, a new character to his work, illuminate his poetic world from a new and interesting side, make it possible to correctly understand the secrets of Sayat-Nova's worldview and his deep poetic meditations. Indeed, the scope of Sayat-Nova's edifying poems appealing to reason are quite wide. Here the poet reflects on the most diverse phenomena of life and the universe - eternal and transitory, man and the world, life and death, soul and body, good and evil, love and hate, virtue and sinfulness, truthfulness and falsity, reason, teaching, enlightenment and ignorance and etc...

"As the most accomplished early modern Armenian ašugh, Sayat-Nova surpasses

other bards in the diversity of genres he practices, the superiority in the rhymes and vocal harmony he develops, the opulence, magnificence and originality of his rhetoric, and the vigor and ardor of his love, as concluded by senior scholars" [7, p. 285].

Most of his songs are composed with certain melodies (there are song duplicates in the words or additional repetitions of the words related to the private horse of the melody). Continuing the tradition that started from Naghash Hovnatan, Sayat-Nova endowed many of his songs with his own special ways. He used the traditional ashugh methods, in which case he attached a note suggesting the weather to the verse. Both melodies have reached us practically through oral transmission. 27 melodies of Armenian songs were collected and written by M. Aghayan l. Sh. Talyan (ed. E., 1946 lı 1963), there are similar methods or variants among the people.

"The basis of Sayat-Nova's melodies is the Armenian monodic music (folk-gusana-troubadour song, medieval poems, urban folk-instrumental instrument), the intonations of that music the sounds revealed by them with their essential features are the main factor in the creation of his melodies. The musical art of the Sayat-Nova troubadour also incorporated some elements and features from the everyday music of Tbilisi (Georgia), which at that time united various national traditions that were part of Middle Eastern music" [8].

All these elements, both in the ashugh's own melodies and in the traditional ones used, have been "edited", merged and reproduced in a single style, which is characterized as Sayat-Nov style, according to the author's creative thinking. The currently popular styles of Sayat-Nova's songs are, for the most part, the product of outstanding mastery.

Commonly troubadour, they use both song and song tricks, bringing a noticeable inner diversity to the finished forms unfolding on similar principles. Sometimes melodies flow in complex combinations of different sounds, with variations of the same melodic structure forming large structures. Interesting are the melodic melodies using elements of other medieval poems and cowboy instrumental music, especially dynamic rhythmic samples, different (two-part-three-part) interpretation of the same rhythm in the melodies with dance composition, accentuation of the poem size, rhythmic accent.

All the songs are emotional, as befits a real troubadour song. Especially in song samples, the expression of the word reaches a deeper expression. The songs that have reached us are small, but they include all the rhythmic intonation and vocal types of Armenian troubadour song. Within the common style, each song has its own unique page. Thus, the Sayat-Nova troubadour stands incomparably higher than the troubadours who sang only traditional melodies and their differences.

Sayat-Nova was also a famous musician, he had a good voice, he accompanied the singing first with saz, then with tambourine-chongur, and finally with his favorite kamancha master. He not only decorated competitions with his art, but also gained wide popularity at that time. Sayat-Nova's art played a great role in the development of Transcaucasian troubadour, and also had a noticeable influence on his compositional work.

History shows that Sayat-Nova was a hugely influential poet and musician throughout Armenia. Even though he spent most of his life in a society steeped in religious fervour he wrote in a romantic style, never afraid to express his true feelings about love and life. He never allowed religion to influence his work in any way with most of his poems and compositions being very much of a secular nature. 
Conclusions. Sayat-Nova has a great service in the field of late medieval Armenian literature and careful culture. He is the culmination of the Armenian troubadour lyric poetry, an artist generously endowed with nature, who revived the cowboy art, which had changed due to the division and decline of the Armenian political independent life, put it in a new direction, revolutionizing the 16th century. The snow and the content of the ashugh poem that has come to an end. In the Caucasus, Sayat-Nova contrasted the Turkish-language games of nomadic singers and musicians in the Middle East, which were widespread in the Middle East, and partly past and stateless, with songs in Armenian and deeply expressing human feelings. the game and personal lyric poetry.

\section{REFERENCES}

1. Artun Ermen. Âşıklık geleneği ve âşık edebiyatı, Karaman Kitabevi, Istanbul, 4th ed., 2011.

2. Greppin John Khachaturian Amaria. A handbook of Armenian dialectology, Caravan Books, Delmar, NY, 1986.

3. Dum-Tragut Jasmine. Armenian. Modern Eastern Armenian, London Oriental and African Language Library, vol. 14, John Benjamins Publishing Company, Amsterdam/Philadelphia, 2009.

4. Tahmizean Nikołos. Sayeat-Novan ew hay gusana-ašufakan erg-eražštutiwně, Drazark Hratarakčutiun, Pasadena, CA, 1995.

5. Muradyan Hrayr. Sayat-Nova: cnndyan 250-amyaki art iv, Haykakan SSR Kałakakan ev Gitakan Gitelikneri Taracman Ënkerutyun, Yerevan, 1963.

6. Levonyan Garegin. Sayat-Nova: hayeren xałeri liakatar žołovacu, Petakan Hratarakčcutyun, Yerevan, 1931.

7. Xi Yang. Sayat-Nova: Within the Near Eastern bardic tradition and posthumous A dissertation submitted in partial satisfaction of the requirements of the degree Doctor of Philosophy in Near Eastern Languages and Cultures. University of California. Los Angele, 2016.

8. Retrieved from http://armenianhouse.org/sayat-nova/bio-am.html 